\section{Dormant Sprigging of Bermudagrass and Zoysiagrass}

\author{
Juming Zhang ${ }^{1}$, Michael Richardson ${ }^{2}$, Douglas Karcher $^{2}$, \\ John McCalla ${ }^{2}$, Jingwen $\mathrm{Mai}^{1}$, and Hanfu $\mathrm{Luo}^{3}$
}

AdDitional INDEX wORDs. Cynodon dactylon, propagation, sod, Zoysia japonica

Summary. Many bermudagrass (Cynodon sp.) and zoysiagrass (Zoysia sp.) cultivars are not available as seed and are commonly planted vegetatively using sprigs, especially for sod production or in sand-based systems. Sprig planting is typically done in late spring or early summer, but this can result in an extended grow-in period and delay the use of the turf in the first growing season. The objective of this study was to determine if sprigs of bermudagrass and zoysiagrass could be planted earlier in the year, during the dormancy phase, to hasten establishment. A field study was carried out in Fayetteville, AR, in 2014 and 2016 using 'Tifway' hybrid bermudagrass (Cynodon dactylon $\times$ Cynodon transvaalensis) and 'Meyer' zoysiagrass (Zoysia japonica), and in Guangzhou, China, in 2015, using 'Tifway' hybrid bermudagrass and 'Lanyin III' zoysiagrass ( $Z$. japonica). Sprigs were planted in March (dormant), May (spring) and July (summer) in Fayetteville, and in January (dormant), March (spring) and May (summer) in Guangzhou. Sprigging rates of 30, 60, and $90 \mathrm{~m}^{3} \cdot \mathrm{ha}^{-1}$ were tested at both locations and across all planting dates. Bermudagrass was less affected by planting date, with dormant, spring or summer plantings effectively establishing full cover in the first growing season. Zoysiagrass that was sprigged in the dormant season was successfully established by the end of the first growing season while a full zoysiagrass cover was not achieved with either spring or summer plantings in Arkansas. Dormant sprigging reached full coverage as fast or faster than traditional spring or summer planting dates at both locations, indicating that bermudagrass and zoysiagrass establishment can be achieved earlier in the growing season using dormant sprigging methods.

$\mathrm{B}$ ermudagrass (Cynodon sp.) and zoysiagrass (Zoysia sp.) are important warm-season turfgrasses and are widely used for sports fields, golf courses, and lawns in tropical, subtropical and transition zone climates (Hanna et al., 2013). Although both grasses are well-known for their

Received for publication 19 Nov. 2020. Accepted fo publication 25 Feb. 2021.

Published online 9 June 2021.

${ }^{1}$ College of Forestry and Landscape Architecture, South China Agricultural University, Guangzhou 510642, China

${ }^{2}$ Department of Horticulture, University of Arkansas, 316 Plant Science Building, Fayetteville, AR 72701

${ }^{3}$ Guangdong Engineering Research Center for Grass land Science, South China Agricultural University, Guangzhou 510642, China

This work was financially supported at South China Agricultural University by grants from the Nationa Grass Cultivar Evaluation Program DUS Testing (No 131721301064072041). At the University of Arkan sas, this project was partially supported by a gift from the U.S. Golf Association and funds provided for technical support by the University of Arkansas, Division of Agriculture

M.R. is the corresponding author. E-mail: mricha@ uark.edu.

This is an open access article distributed under the CC BY-NC-ND license (https://creativecommons.org/ licenses/by-nc-nd/4.0/).

https://doi.org/10.21273/HORTTECH04763-20 durability and tolerance of drought, salinity, pests, and diseases, a significant difference between the two turfgrasses is their growth rate and subsequent ability to establish quickly and recover from injury (Christians et al., 2017). Bermudagrass is a vigorously growing species that produces an abundance of stolons and rhizomes and can quickly establish in a range of turf situations (Hanna et al., 2013). Zoysiagrass also produces abundant stolons and rhizomes, but is generally considered a slow-growing species (Patton, 2009; Patton et al., 2017). Once established, zoysiagrass has lower mowing and fertility requirements compared with bermudagrass and is also slower to invade other areas, which are considered desirable traits. However, the differences in growth rates of the two species plays a major role in the establishment rate and, subsequently, the upfront cost of the grasses (Patton et al., 2004).

Most bermudagrass and zoysiagrass cultivars used for turf are either sterile hybrids or cultivars that produce insufficient quantities of viable seed (Hanna et al., 2013). As such, both species are commonly planted vegetatively by sodding, plugging, or sprigging. Sprigging is a vegetative planting method that places turfgrass stolons or rhizomes onto the soil surface and then incorporates the sprigs to provide adequate soil contact (Richardson and Boyd, 2001). Sprigging is widely used in sandbased turf systems, such as athletic fields and putting greens, or in the establishment of large turf areas like golf course fairways and sod farms (Guertal and Hicks, 2009; Shoulders and Schmidt, 1985).

Bermudagrass and zoysiagrass can both experience winter dormancy periods for up to 6 months, and temperature is a major factor that controls growth and dormancy in warm-season grasses. As such, establishment of warm-season grasses is generally recommended to occur in late spring or early summer months when soil temperatures are capable of initiating and promoting growth. Planting warm-season grasses later in the growing season can increase the risk of winter injury (Musser and Perkins, 1969) and also extend the grow-in period into a second season. Sprigged cultivars of bermudagrass can yield three to five sod crops in 24 months when environmental conditions are suitable, while a single crop of zoysiagrass sod will often require 15 to 24 months to reach maturity from sprig establishment (Engelke, 1988; Richardson and Boyd, 2001; Richardson et al., 2003). Because of this slow establishment,

\begin{tabular}{llll}
\hline $\begin{array}{l}\text { Units } \\
\begin{array}{l}\text { To convert U.S. to SI, } \\
\text { multiply by }\end{array}\end{array}$ & U.S. unit & SI unit & $\begin{array}{l}\text { To convert SI to U.S., } \\
\text { multiply by }\end{array}$ \\
\hline 0.3048 & $\mathrm{ft}$ & $\mathrm{m}$ & 3.2808 \\
0.0700 & $\mathrm{ft} / \mathrm{acre}$ & $\mathrm{m}^{3} \cdot \mathrm{ha}^{-1}$ & 14.2913 \\
2.54 & inch $(\mathrm{es})$ & $\mathrm{cm}$ & 0.3937 \\
25.4 & inch $(\mathrm{es})$ & $\mathrm{mm}$ & 0.0394 \\
1.1209 & $\mathrm{lb} / \mathrm{acre}$ & $\mathrm{kg} \cdot \mathrm{ha}^{-1}$ & 0.8922 \\
62.5000 & $\mathrm{oz} / \mathrm{lb}$ & $\mathrm{g} \cdot \mathrm{kg}^{-1}$ & 0.0160 \\
33.9057 & $\mathrm{oz} / \mathrm{yard}^{2}$ & $\mathrm{~g} \cdot \mathrm{m}^{-2}$ & 0.0295 \\
$\left({ }^{\circ} \mathrm{F}-32\right) \div 1.8$ & ${ }^{\circ} \mathrm{F}$ & ${ }^{\circ} \mathrm{C}$ & $\left({ }^{\circ} \mathrm{C} \times 1.8\right)+32$ \\
& & &
\end{tabular}

Hortlechnology $\cdot$ August $202131(4)$ 
zoysiagrass is rarely propagated on golf course or landscape sites from sprigs, but rather from established sod, which adds substantially to the initial cost (Patton et al., 2004).

Planting rate is another factor affecting warm-season turfgrass establishment from sprigs. Studies have reported successful establishment of bermudagrass with sprigging rates ranging from 20 to $80 \mathrm{~m}^{3} \cdot \mathrm{ha}^{-1}$ (Baseggio et al., 2015; Brosnan et al., 2014; Guertal and Hicks, 2009). Research has tested zoysiagrass sprigging rates ranging from 30 to $180 \mathrm{~m}^{3} \cdot \mathrm{ha}^{-1}$, and faster establishment has typically been observed with higher rates. Methods to enhance sprig survival, such as topdressing, can also improve the establishment of zoysiagrass (Engelke, 1988; Richardson and Boyd, 2001; Richardson et al., 2003; Stiglbauer et al., 2009).

Dormant seeding refers to planting seed in winter or early spring when soil temperatures are outside the normal range for germination (Reicher et al., 2000). It has been effectively used for establishing coolseason turfgrasses (Ross, 2003) and has also been effective with a range of warmseason turfgrasses (Giolo et al., 2020; Pornaro et al., 2016; Shaver et al., 2006). Dormant sprigging is a less common practice, but has been recommended with forage bermudagrasses in the southeastern United States (Chamblee et al., 1989; Mueller et al., 1981) and has been briefly mentioned in the turfgrass literature (Ruemmele et al., 1993; Shoulders and Schmidt, 1985). In Blacksburg, VA, Shoulders and Schmidt (1985) observed that 'Tifway' and 'Vamont' hybrid bermudagrasses ( $C$. dactylon $\times C$. transwaalensis) were slow to establish when sprigged very early in the spring. Recent work from Virginia (Herrmann et al., 2020) has also demonstrated good success of dormant sprigging a hybrid bermudagrass cultivar.

A more comprehensive study by Ruemmele et al. (1993) was conducted in Dallas, TX, using 'Tifway' hybrid bermudagrass and 'Belair' zoysiagrass ( $Z$. japonica) sprigged monthly throughout the year. In that study, zoysiagrass sprig plantings in late winter (Jan-March) established slowly or not at all, whereas the bermudagrass showed good establishment at 8 months after planting. Although the studies had limited success with dormant sprigging, the trials used much lower sprigging rates than recommended, which may have impacted the overall results. A sprigging rate in volume per area was not reported in that study, but we estimated their rate to be in the range of 5-10 $\mathrm{m}^{3} \cdot \mathrm{ha}^{-1}$ based on a harvest depth of $3 \mathrm{~cm}$. The objective of the present study was to examine the effects of planting date and sprigging rate on the establishment of bermudagrass and zoysiagrass in transitional and subtropical regions. Our hypothesis was that successful establishment of zoysiagrass and bermudagrass from sprigs could be attained over a range of planting dates and planting rates.

\section{Materials and methods}

LOCATIONS AND EXPERIMENTAL CONDITIONS. A field study was conducted over 3 years and included sites that are considered transition zone and subtropical. The transition zone study was conducted in 2014 and 2016 at the Milo J. Shult Agricultural Research \& Extension Center in Fayetteville, AR (lat. $36.101600^{\circ} \mathrm{N}$, long. $94.168278^{\circ} \mathrm{W}$ ) and the turfgrass cultivars included Tifway hybrid bermudagrass and Meyer zoysiagrass (Z. japonica). In 2015, the study was conducted at the Teaching and Research Center of South China Agricultural University, Guangzhou, China (lat. 23.298611 ${ }^{\circ} \mathrm{N}$, long. $113.810000^{\circ} \mathrm{E}$ ), using 'Tifway' bermudagrass and 'Lanyin III' zoysiagrass ( $Z$. japonica). The soil type in Fayetteville was a Captina silt loam (fine-silty, siliceous, active, mesic Typic Fragiudults) with an organic matter of $10.2 \mathrm{~g} \cdot \mathrm{kg}^{-1}$ and an average $\mathrm{pH}$ of 6.2 . The native soil type in Guangzhou was a Lateritic red clay soil with an organic matter of 14.5 $\mathrm{g} \cdot \mathrm{kg}^{-1}$ and an average $\mathrm{pH}$ of 6.3 . This native soil was modified by incorporating sand to a depth of $10 \mathrm{~cm}$ to improve soil structure and drainage capacity. The sand used in the study had a particle size distribution that was primarily composed of very coarse $(9.6 \%)$, coarse (19.5), medium (34.9), and fine (19.7) sand sizes.

As the comparison of species was not of particular interest in this study, bermudagrass and zoysiagrass were established as separate trials to avoid any contamination. The two treatment factors considered in the study were planting date and planting rate. The experimental design for each species was a randomized complete block, split-plot design with planting date as the whole plot and planting rate as the split plot. Whole plots (planting date) were $9.0 \times 1.4 \mathrm{~m}$ in Fayetteville and $6.0 \times 1.5 \mathrm{~m}$ in Guangzhou, and the split plots (sprigging rate) were $3.0 \times 1.4 \mathrm{~m}$ in Fayetteville and $2.0 \times 1.5 \mathrm{~m}$ in Guangzhou. All treatment combinations were replicated three times within each trial.

The experimental areas at both locations were tilled to an approximate depth of $10 \mathrm{~cm}$ and leveled immediately before each planting date. In Fayetteville, sprig planting dates included 28 Mar. (dormant), 30 May (spring), and 22 July (summer) in 2014, and 18 Mar. (dormant), 13 May (spring), and l July (summer) in 2016. In Guangzhou, sprig planting dates were 21 Jan. (dormant), 18 Mar. (spring), and 25 May (summer) in 2015. Warm-season grasses do not experience the same level of dormancy in Guangzhou as Fayetteville, but it was estimated that the sod was $90 \%$ dormant at the time of harvest for the January planting. For each planting date, three sprigging rates of each species were compared, including 30 , 60 , and $90 \mathrm{~m}^{3} \cdot \mathrm{ha}^{-1}$. Sprigs for the experiment were either processed from sod onsite (2014 and 2015) or provided directly from a sod producer (2016). For onsite preparation from sod, the sod was washed free of soil and then shredded into sprigs by passing the sod through a chippershredder. Plots were planted by spreading the appropriate volume of sprigs on the native soil, topdressing the plots with $1 \mathrm{~cm}$ of sand with a track-mounted top-dresser, and then the soil was firmed with either the turf tires on a tractor or a light roller.

In Fayetteville, oxadiazon (Ronstar G; Bayer Environmental Sciences, Cary, NC) was applied to all plots at $3.0 \mathrm{lb} /$ acre a.i. immediately after planting to suppress annual grassy weeds, and broadleaf weeds were controlled as needed using a common three-way herbicide (Trimec Southern; PBI Gordon Co., Shawnee, KS) applied at label rates. In Guangzhou, weed control included applications of 2-methyl-4-chlorophenoxyacetic acid (MCPA) at labeled rates to control broadleaf weeds, and grassy weeds were manually removed. Plots were irrigated as needed to prevent sprig desiccation and promote establishment, and 
Table 1. Model parameters for nonlinear regression, examining the effects of planting season and planting rate on day of year (DOY) to reach either $50 \%$ or $90 \%$ turfgrass coverage with zoysiagrass.

\begin{tabular}{|c|c|c|c|c|c|c|c|c|c|c|}
\hline \multirow[b]{2}{*}{ Yr } & \multirow{2}{*}{$\begin{array}{c}\text { Planting } \\
\text { season }\end{array}$} & \multirow{2}{*}{$\begin{array}{l}\text { Planting } \\
\text { rate } \\
\left(\mathrm{m}^{3} \cdot \mathrm{ha}^{-1}\right)^{\mathrm{z}}\end{array}$} & \multirow[b]{2}{*}{ Slope } & \multirow[b]{2}{*}{$R^{2}$} & $\begin{array}{c}\text { Lower } \\
95 \% \text { CI }^{\mathrm{y}} \\
\end{array}$ & Mean & $\begin{array}{c}\text { Upper } \\
95 \% \mathrm{CI} \\
\end{array}$ & $\begin{array}{c}\text { Lower } \\
\mathbf{9 5 \%} \mathrm{CI} \\
\end{array}$ & Mean & $\begin{array}{c}\text { Upper } \\
95 \% \mathrm{CI} \\
\end{array}$ \\
\hline & & & & & \multicolumn{3}{|c|}{ DOY to $50 \%$ coverage $^{\mathrm{y}}$} & \multicolumn{3}{|c|}{ DOY to $90 \%$ coverage $^{\mathrm{y}}$} \\
\hline \multirow[t]{9}{*}{2014} & Dormant & 30 & 0.0369 & 0.951 & 171.2 & 174.8 & 178.5 & 192.8 & 200.7 & 208.6 \\
\hline & & 60 & 0.0312 & 0.943 & 167.4 & 171.6 & 175.8 & 193.1 & 202.2 & 211.3 \\
\hline & & 90 & 0.0305 & 0.966 & 174.2 & 177.5 & 180.8 & 201.7 & 208.8 & 215.8 \\
\hline & Spring & 30 & 0.0262 & 0.944 & 234.3 & 237.7 & 241.2 & 266.4 & 274.2 & 282.0 \\
\hline & & 60 & 0.0363 & 0.983 & 217.1 & 219.0 & 220.9 & 241.2 & 245.3 & 249.4 \\
\hline & & 90 & 0.0332 & 0.976 & 222.0 & 224.3 & 226.6 & 248.1 & 253.1 & 258.0 \\
\hline & Summer & 30 & 0.0170 & 0.768 & 276.4 & 285.6 & 294.7 & 316.3 & 341.8 & 367.4 \\
\hline & & 60 & 0.0230 & 0.930 & 252.9 & 256.3 & 259.6 & 289.1 & 297.9 & 306.0 \\
\hline & & 90 & 0.0217 & 0.803 & 256.2 & 262.1 & 268.1 & 289.6 & 306.1 & 322.6 \\
\hline \multirow[t]{9}{*}{2015} & Dormant & 30 & 0.0278 & 0.990 & 99.3 & 101.1 & 102.8 & 131.7 & 135.4 & 139.2 \\
\hline & & 60 & 0.0286 & 0.986 & 97.7 & 99.7 & 101.7 & 128.8 & 133.1 & 137.4 \\
\hline & & 90 & 0.0266 & 0.991 & 97.2 & 98.9 & 100.5 & 131.2 & 134.7 & 138.3 \\
\hline & Spring & 30 & 0.0259 & 0.974 & 148.3 & 151.0 & 153.7 & 181.7 & 187.8 & 193.9 \\
\hline & & 60 & 0.0261 & 0.972 & 149.0 & 151.7 & 154.5 & 182.1 & 188.4 & 194.6 \\
\hline & & 90 & 0.0261 & 0.957 & 148.3 & 151.8 & 155.2 & 180.6 & 188.3 & 196.0 \\
\hline & Summer & 30 & 0.0481 & 0.997 & 179.9 & 180.6 & 181.3 & 198.9 & 200.4 & 202.0 \\
\hline & & 60 & 0.0458 & 0.997 & 180.1 & 180.8 & 181.4 & 200.2 & 201.6 & 203.1 \\
\hline & & 90 & 0.0498 & 0.995 & 179.3 & 180.2 & 181.1 & 197.4 & 199.4 & 201.4 \\
\hline \multirow[t]{9}{*}{2016} & Dormant & 30 & 0.0281 & 0.976 & 168.1 & 171.3 & 174.5 & 198.1 & 205.2 & 212.4 \\
\hline & & 60 & 0.0280 & 0.978 & 166.1 & 169.2 & 172.3 & 196.4 & 203.3 & 210.3 \\
\hline & & 90 & 0.0250 & 0.964 & 166.6 & 170.8 & 175.0 & 199.9 & 209.0 & 218.1 \\
\hline & Spring & 30 & 0.0244 & 0.911 & 219.9 & 224.5 & 229.1 & 251.3 & 263.7 & 276.0 \\
\hline & & 60 & 0.0231 & 0.949 & 220.2 & 223.8 & 227.3 & 255.6 & 265.2 & 274.7 \\
\hline & & 90 & 0.0237 & 0.968 & 219.0 & 222.5 & 226.1 & 253.4 & 262.8 & 272.2 \\
\hline & Summer & 30 & 0.0226 & 0.946 & 244.5 & 248.0 & 251.4 & 280.0 & 290.2 & 300.5 \\
\hline & & 60 & 0.0291 & 0.963 & 231.3 & 233.7 & 236.1 & 260.1 & 266.5 & 272.9 \\
\hline & & 90 & 0.0321 & 0.978 & 227.6 & 229.4 & 231.3 & 254.4 & 259.2 & 263.9 \\
\hline
\end{tabular}

${ }^{\mathrm{z}} 1 \mathrm{~m}^{3} \cdot \mathrm{ha}^{-1}=14.2913 \mathrm{ft}^{3} /$ acre.

${ }^{y}$ DOY to reach either $50 \%$ or $90 \%$ turfgrass coverage. Within years, means for each treatment combination were considered statistically different if their $95 \%$ confidence intervals (CI) did not overlap.

mowing was initiated at a height of 1 inch once the plots were established well enough to mow. It should be noted that irrigation was rarely required during establishment of the dormant planting dates due to more consistent rainfall and reduced evaporative demand. Plots were fertilized monthly with urea $(46 \mathrm{~N}-0 \mathrm{P}-0 \mathrm{~K})$ at 2.5 $\mathrm{g} \cdot \mathrm{m}^{-2} \mathrm{~N}$ for zoysiagrass and $5.0 \mathrm{~g} \cdot \mathrm{m}^{-2}$ $\mathrm{N}$ for bermudagrass.

At the Fayetteville site, average turfgrass coverage was monitored weekly after sprigging using digital image analysis (Richardson et al., 2001) of two images from each plot. Data were collected only until the turf started experiencing early signs of dormancy (typically $\approx 1$ Oct. 2014 and 2016) and data collection was not continued in the following season on zoysiagrass because numerous studies have documented an 18- to 24-month establishment period for zoysiagrass. In Guangzhou, turfgrass coverage was assessed weekly using a $50 \times 50-\mathrm{cm}$ frame with strings evenly spaced at $5-\mathrm{cm}$ intervals to form 100 intersects. The grid was randomly tossed on each plot and the number of intersects with green turfgrass leaves was counted to determine percent coverage.

GrowING DEGREE DAYs. Growing degree days (GDD) were calculated for each planting date within each season using the following equation:

$$
\begin{aligned}
& \text { [(maximum daily temperature } \\
& \quad+\text { minimum daily temperature }) / 2)] \\
& \quad \text { - basal growth temperature }
\end{aligned}
$$

The basal growth temperature used in the present study was $5{ }^{\circ} \mathrm{C}$ based on previous work by Unruh et al. (1996). Daily, accumulated GDD units were summarized for each planting date using the planting date as day $=0$.
Statistical analysis. Preliminary review of the raw data suggested that, for each species and year, green turf coverage increased relative to day of year (DOY) in a nonlinear, sigmoid-shaped fashion. Therefore, nonlinear regression was performed using GraphPad Prism (version 6.0; GraphPad Software, San Diego, CA) with the following variable slope sigmoid model to determine the relationship between turf coverage and DOY for each combination of year, species, planting season, and planting rate:

$$
\begin{aligned}
& \text { green turf cover(percent) } \\
& \quad=100 /\left[1+10^{\left.\left(\text {Days }_{50}-\text { DOY }\right) \times \text { slope }\right)}\right],
\end{aligned}
$$

where DOY = day of year and $\mathrm{DOY}_{50}$ and slope are estimated model parameters. Days 50 is the DOY when green turf coverage reaches $50 \%$. The slope parameter defines how rapidly turf coverage changes over time with larger 
Table 2. Model parameters for nonlinear regression, examining the effects of planting season and planting rate on day of year (DOY) to reach either $\mathbf{5 0 \%}$ or $\mathbf{9 0 \%}$ turfgrass coverage with bermudagrass.

\begin{tabular}{|c|c|c|c|c|c|c|c|c|c|c|}
\hline \multirow[b]{2}{*}{ Yr } & \multirow{2}{*}{$\begin{array}{c}\text { Planting } \\
\text { season }\end{array}$} & \multirow{2}{*}{$\begin{array}{c}\text { Planting } \\
\text { rate } \\
\left(\mathrm{m}^{3} \cdot \mathrm{ha}^{-1}\right)^{\mathrm{z}}\end{array}$} & \multirow[b]{2}{*}{ Slope } & \multirow[b]{2}{*}{$R^{2}$} & $\begin{array}{c}\text { Lower } \\
95 \% \text { CI }^{\mathrm{y}}\end{array}$ & Mean & $\begin{array}{c}\text { Upper } \\
95 \% \text { CI }\end{array}$ & $\begin{array}{c}\text { Lower } \\
95 \% \text { CI }\end{array}$ & Mean & $\begin{array}{c}\text { Upper } \\
95 \% \text { CI }\end{array}$ \\
\hline & & & & & \multicolumn{3}{|c|}{ DOY to $50 \%$ coverage $^{\mathrm{y}}$} & \multicolumn{3}{|c|}{ DOY to $90 \%$ coverage $^{\mathrm{y}}$} \\
\hline \multirow[t]{9}{*}{2014} & Dormant & 30 & 0.0616 & 0.995 & 133.3 & 134.1 & 134.8 & 147.9 & 149.5 & 151.2 \\
\hline & & 60 & 0.0655 & 0.991 & 128.0 & 128.9 & 129.9 & 141.4 & 143.5 & 145.7 \\
\hline & & 90 & 0.0647 & 0.986 & 127.7 & 128.9 & 130.1 & 141.0 & 143.7 & 146.3 \\
\hline & Spring & 30 & 0.1790 & 0.987 & 175.4 & 178.0 & 180.6 & 181.7 & 183.3 & 184.9 \\
\hline & & 60 & 0.1766 & 0.984 & 175.6 & 178.5 & 181.4 & 182.2 & 183.9 & 185.5 \\
\hline & & 90 & 0.2084 & 0.963 & 171.4 & 176.5 & 181.5 & 176.1 & 181.1 & 186.1 \\
\hline & Summer & 30 & 0.1090 & 0.997 & 220.8 & 221.3 & 221.9 & 229.0 & 230.1 & 231.2 \\
\hline & & 60 & 0.0959 & 0.997 & 219.1 & 219.7 & 220.3 & 228.6 & 229.6 & 230.6 \\
\hline & & 90 & 0.0968 & 0.997 & 219.8 & 220.4 & 221.1 & 229.2 & 230.3 & 231.4 \\
\hline \multirow[t]{9}{*}{2015} & Dormant & 30 & 0.0427 & 0.974 & 48.9 & 50.3 & 51.7 & 69.4 & 72.7 & 75.9 \\
\hline & & 60 & 0.0399 & 0.990 & 45.8 & 46.6 & 47.4 & 68.6 & 70.5 & 72.5 \\
\hline & & 90 & 0.0390 & 0.973 & 43.0 & 44.4 & 45.7 & 65.7 & 68.9 & 72.0 \\
\hline & Spring & 30 & 0.0238 & 0.989 & 136.6 & 138.5 & 140.4 & 174.5 & 178.6 & 182.8 \\
\hline & & 60 & 0.0296 & 0.993 & 124.8 & 126.3 & 127.8 & 155.3 & 158.6 & 161.8 \\
\hline & & 90 & 0.0322 & 0.995 & 124.5 & 125.8 & 127.0 & 152.8 & 155.4 & 158.1 \\
\hline & Summer & 30 & 0.0741 & 0.998 & 153.5 & 154.0 & 154.5 & 165.7 & 166.9 & 168.1 \\
\hline & & 60 & 0.1023 & 0.999 & 150.5 & 150.8 & 151.1 & 159.1 & 160.1 & 161.1 \\
\hline & & 90 & 0.1013 & 0.999 & 150.4 & 150.7 & 151.0 & 159.0 & 160.1 & 161.3 \\
\hline \multirow[t]{9}{*}{2016} & Dormant & 30 & 0.0617 & 0.984 & 140.4 & 142.3 & 144.3 & 153.4 & 157.8 & 162.2 \\
\hline & & 60 & 0.0644 & 0.998 & 137.0 & 137.6 & 138.1 & 150.4 & 152.4 & 154.0 \\
\hline & & 90 & 0.0696 & 0.994 & 140.9 & 142.1 & 143.2 & 152.8 & 155.8 & 158.6 \\
\hline & Spring & 30 & 0.0333 & 0.991 & 221.2 & 222.5 & 223.8 & 248.0 & 251.1 & 254.2 \\
\hline & & 60 & 0.0331 & 0.985 & 182.4 & 185.0 & 187.7 & 213.8 & 213.8 & 218.9 \\
\hline & & 90 & 0.0239 & 0.934 & 204.1 & 209.0 & 213.8 & 237.6 & 248.8 & 260.1 \\
\hline & Summer & 30 & 0.0394 & 0.986 & 219.4 & 221.0 & 222.6 & 241.4 & 245.2 & 249.0 \\
\hline & & 60 & 0.0377 & 0.986 & 218.9 & 220.5 & 222.1 & 242.0 & 245.8 & 249.6 \\
\hline & & 90 & 0.0323 & 0.988 & 215.0 & 216.6 & 218.2 & 242.3 & 246.1 & 250.0 \\
\hline
\end{tabular}

${ }^{\mathrm{z}} 1 \mathrm{~m}^{3} \cdot \mathrm{ha}^{-1}=14.2913 \mathrm{ft}^{3} /$ acre.

${ }^{y}$ DOY to reach either $50 \%$ or $90 \%$ turfgrass coverage. Within years, means for each treatment combination were considered statistically different if their $95 \%$ confidence intervals (CI) did not overlap.

values representing steeper slopes of the sigmoid curve. The DOY when turf coverage reached $90 \%\left(\mathrm{DOY}_{90}\right)$ was also estimated for each treatment combination, as $90 \%$ coverage was considered by the authors to be a desirable level of coverage for sports turf or sod production. Confidence intervals (95\%) were calculated for $\mathrm{DOY}_{50}$ and $\mathrm{DOY}_{90}$ parameter estimates to compare treatment levels. Within species and years, treatment combinations of planting season and rate were considered significantly different if their confidence intervals did not overlap. After $\mathrm{DOY}_{90}$ parameters were developed, the accumulated GDD units required to reach $\mathrm{DOY}_{90}$ coverage were determined for each year and treatment combination.

\section{Results and discussion}

Temperature and precipitation data are presented for each site and year combination (Fig. 1). Weather patterns during 2014 and 2016 at Fayetteville, AR, were considered typical for the region, with adequate rainfall $(70-110 \mathrm{~mm} /$ month $)$ from May to June and more irregular rainfall patterns $(40-180 \mathrm{~mm} / \mathrm{month})$ during July and August. For Gaungzhou (2015), typical seasonal rainfall patterns for the region were observed (Fig. 1). Moderate rainfall (50-100 $\mathrm{mm} /$ month) was observed early in the planting season (January to March) and more heavy rainfall (150-300 $\mathrm{mm} /$ month) was observed beginning in April and continuing through October. Temperature patterns for all sites and seasons were also considered consistent with the long-term averages for each region. Because each year and location had variable planting and evaluation dates, the data were subsequently analyzed by year and species. The sigmoid models used to predict turf coverage (Figs. 2 and 3 ) provided a good fit of the green turf coverage data, resulting in average $R^{2}$ values of 0.90 and higher for both bermudagrass and zoysiagrass across the 3 trial years (Tables 1 and 2). Although DOY $_{50}$ is a metric needed to generate the curves associated with treatments, all discussion is focused on the $\mathrm{DOY}_{90}$ data because those are most relevant to the objective of the study.

ZoYSIAGRASS ESTABLISHMENT. Sprigging date had a significant effect on DOY $_{90}$ in zoysiagrass across all 3 years of the study (Table 1, Fig. 2). Overall, more rapid and complete establishment was observed each year from a dormant sprigging date compared with spring or summer plantings. This response was observed in both transition zone (2014 and 2016 in Fayetteville) and subtropical environments (2015 in Guangzhou). The DOY for dormant sprigs to reach $90 \%$ 


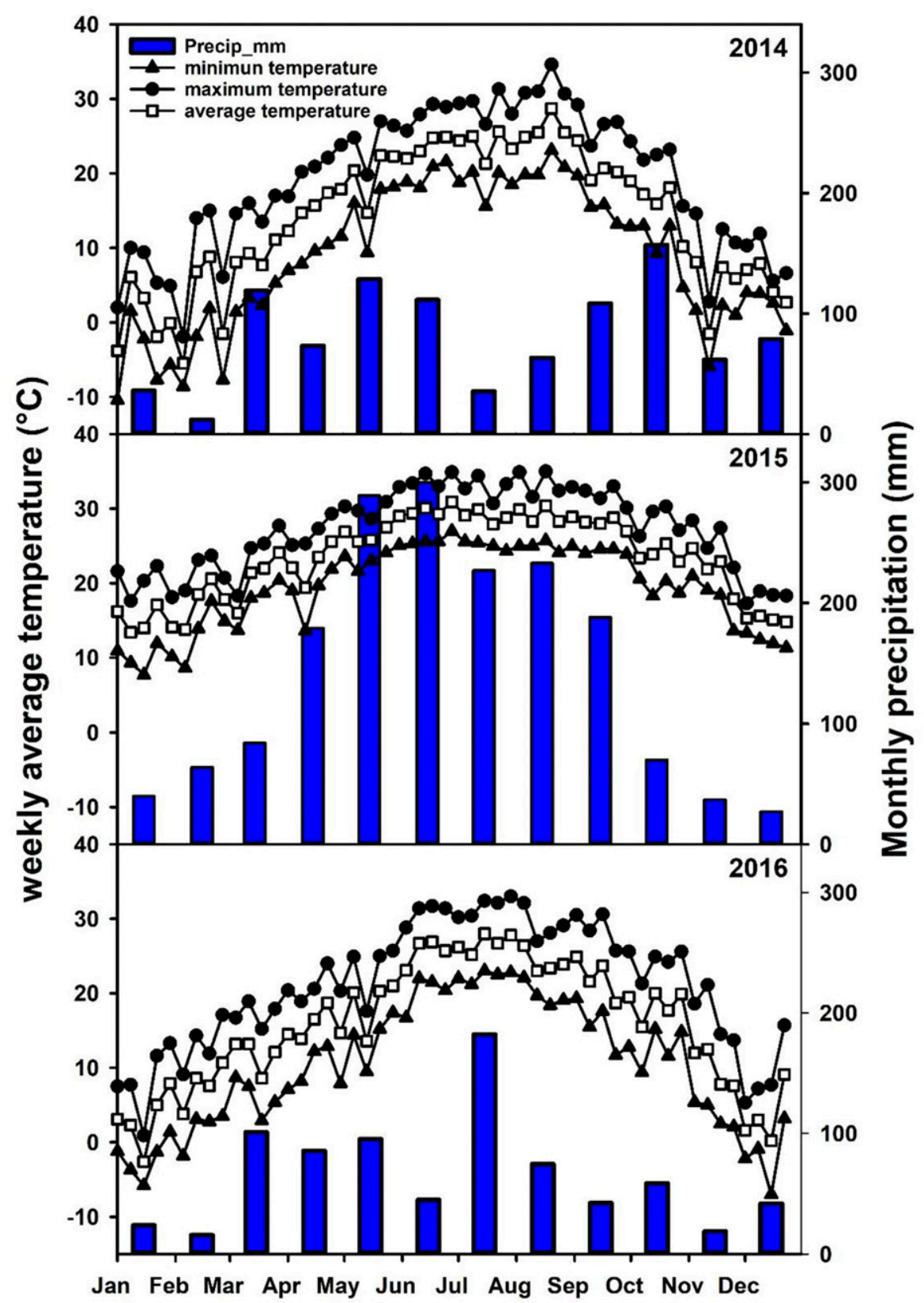

Fig. 1. Temperature and precipitation at the Fayetteville, AR, site in 2014 and 2016 and the Guangzhou, China, site in 2015; $\left(1.8 \times{ }^{\circ} \mathrm{C}\right)+32={ }^{\circ} \mathrm{F}, 1 \mathrm{~mm}=$ 0.0394 inch.

turfgrass coverage was generally 50 to $60 \mathrm{~d}$ earlier than spring planting treatments (Table 1), suggesting that early planting of zoysiagrass sprigs could produce a harvestable sod crop in the first year of planting.

It should be noted that spring and summer plantings of zoysiagrass did not actually reach $100 \%$ coverage by the end of the 2014 and 2016 growing seasons in Fayetteville (Fig. 2 ), even though the parameter estimates (Table 1) suggest they did. The authors recognize a deficiency in zoysiagrass in Indiana has also been documented to cease in early September (Patton et al., 2007), which would correspond to late September conditions in Fayetteville, AR. The model uses coverage data collected while the grass was still green to predict a DOY to reach a predefined coverage percentage such as $90 \%$, but, in this case, that prediction is based on the assumption that the turf continues to grow. As such, the DOY estimates to reach $90 \%$ coverage (Table 1), especially for the summer plantings in Fayetteville, are recognized to be an inaccurate reflection of when those plots reached full maturity, which occurred in midsummer of the following growing season (data not shown).

Sprigging rate affected zoysiagrass establishment, but only in 2014 and 2016, and only with the spring and summer planting dates (Table 1, Fig. 2). In 2014, there were no differences in the 60- and $90-\mathrm{m}^{3} \cdot \mathrm{ha}^{-1}$ rates for the spring and summer planting dates, but the 30$\mathrm{m}^{3} \cdot \mathrm{ha}^{-1}$ rate took significantly longer to establish than either of the higher rates for both the spring and summer plantings. It was interesting to note that rate did not affect establishment during the dormant sprigging for any of the trial years (Fig. 2). Although the authors did not attempt to quantify this in the present study, observations suggest that dormant sprigs may not be affected as much by desiccation as sprigs planted during the warmer parts of the year, which may enhance the overall viability of sprigs and result in higher numbers of live plants. Webb (1959) demonstrated that stolons of 'Coastal' bermudagrass harvested late in the dormancy period retained moisture at a much higher percentage than stolons harvested during active growth periods. That work suggests dormant sprigs may tolerate desiccation more than stolons harvested from actively growing plants, which would likely lead to higher sprig survival.

Sprigging date had a significant effect on zoysiagrass coverage in all 3 years of the trial and dormant sprigging allowed full coverage $(>90 \%)$ to be attained in the first growing season. Numerous studies have investigated various planting rates, planting methods, and cultural practices to hasten establishment of zoysiagrass (Engelke, 1988; McCarty and Miller, 


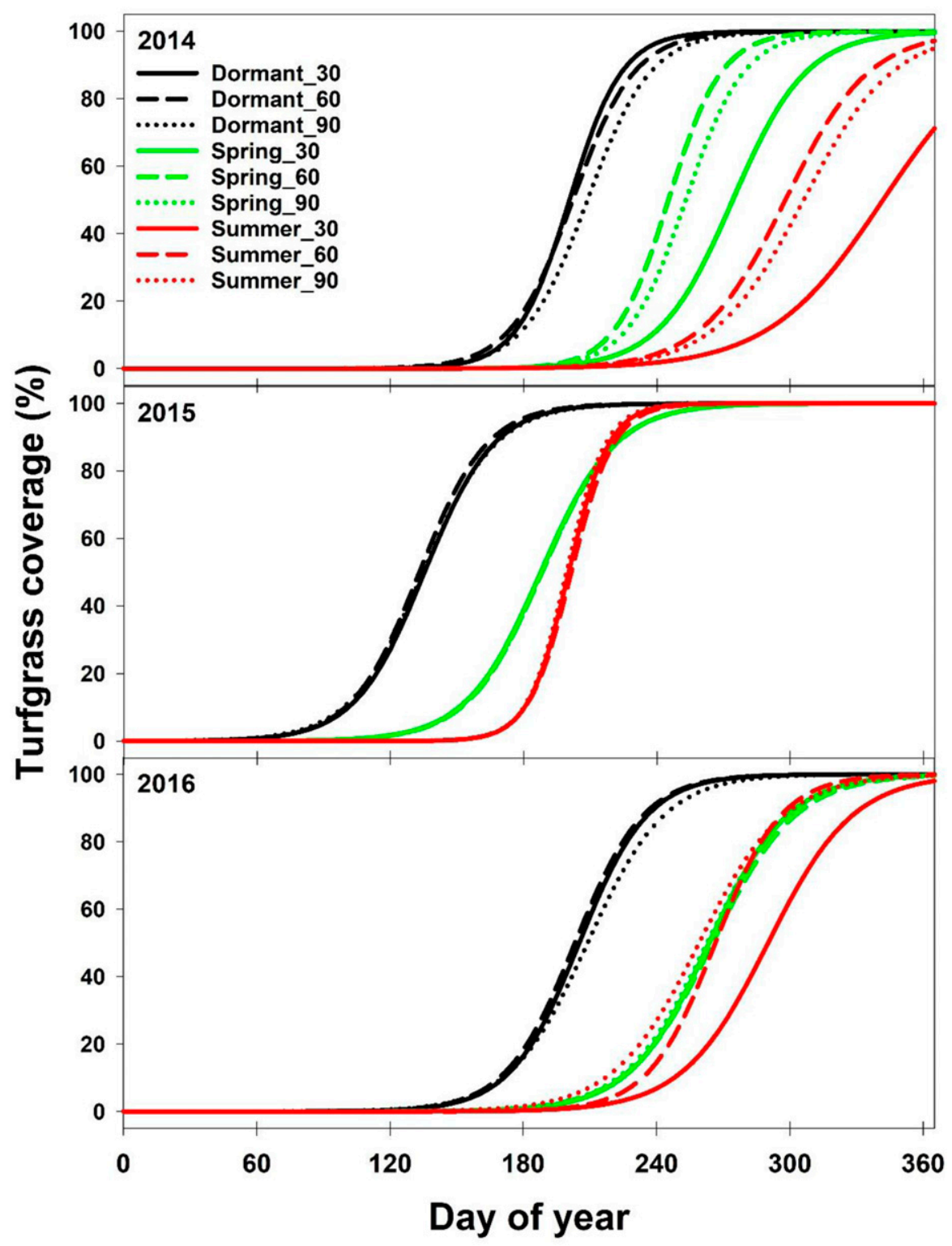

Fig. 2. Establishment of zoysiagrass from sprigs planted during three seasons (dormant, spring, and summer) and with three planting rates $(30,60$, and $\left.90 \mathrm{~m}^{3} \cdot \mathrm{ha}^{-1}\right) ; 1 \mathrm{~m}^{3} \cdot \mathrm{ha}^{-1}=14.2913 \mathrm{ft}^{3} /$ acre.

2002; Richardson and Boyd, 2001). The results of this study and others suggests that zoysiagrass planted at traditional spring or summer planting dates in transition zone regions cannot be fully established in the current growing season. In contrast, dormant sprigging of zoysiagrass repeatedly resulted in a successful, first-year establishment, which could be significant for sod producers to lower their production costs. One previous study (Ruemmele et al., 1993) included dormant sprigging of zoysiagrass in Dallas, TX, and reported that 'Belair' zoysiagrass did not establish complete coverage in one growing season when planted during the dormant season. That study did use much lower sprigging rates $\left(7.2\right.$ or $\left.14.1 \mathrm{~m}^{3} \cdot \mathrm{ha}^{-1}\right)$ than the present study and those lower rates may have influenced the overall results.

Bermudagrass ESTABLISHMENT. With bermudagrass, all sprigging date and rate treatments reached $90 \%$ coverage by the end of the first growing season (Table 2, Fig. 3). Sprigging date had a more pronounced effect on $\mathrm{DOY}_{90}$ than sprigging rate in bermudagrass across all 3 years of the study (Table 2, Fig. 3). Interestingly, in all 3 years, dormant-sprigged bermudagrass had reached $90 \%$ coverage at or near when spring plantings occurred. Sprigging rate effects on bermudagrass were somewhat inconsistent across the 3 trial years, but in most instances there were minimal differences among the three rates (Table 2, Fig. 3). In 2015, the low sprigging rate had a delayed establishment compared with the medium and high rates by $\approx 20 \mathrm{~d}$, but this was not observed in either 2014 or 2016.

In 2015 and 2016, springplanted bermudagrass sprigs were slow to establish and did not perform consistently better than summerplanted treatments (Table 2, Fig. 3). This was unexpected, but may be a reflection of sprig quality and vitality at various times of the season. Quality of vegetative planting material has been shown to affect establishment success of 'Tifton 85' hybrid bermudagrass (Baseggio et al., 2015) and elephantgrass [Pennisetum purpureum (Rusland et al., 1993)]. It has also been well-documented that bermudagrass is very sensitive to chemical treatments during the spring green-up period (Johnson, 1980). As bermudagrass shifts from the dormancy phase to spring growth, there may be a critical period when the vitality or vigor of vegetative sprigs is compromised. It has been shown that rhizome and stolon carbohydrate reserves are typically at their lowest point during the spring green-up period (Miller and Dickens, 1996; Schiavon et al., 2016), possibly impacting the initiation and growth of vegetative sprigs. It is also assumed that some "transplant shock" occurs when sprigs are harvested and planted, so weakened plants in the spring may be more susceptible to this shock than dormant or summer-planted sprigs. These would all be interesting questions for future research.

For summer plantings in both locations, bermudagrass reached full coverage from 4 to 8 weeks after planting. Guertal and Evans (2006) reported that the cultivar, TifEagle, required 7 to 9 weeks after planting sprigs during summer to reach $90 \%$ coverage. Others have reported similar grow-in periods with other bermudagrass cultivars (Bingham and Hall, 1985; Keeley and Thullen, 1989). Although dormant sprigging dates typically required 8 to 10 weeks from planting for full establishment in the present study, they were also established 


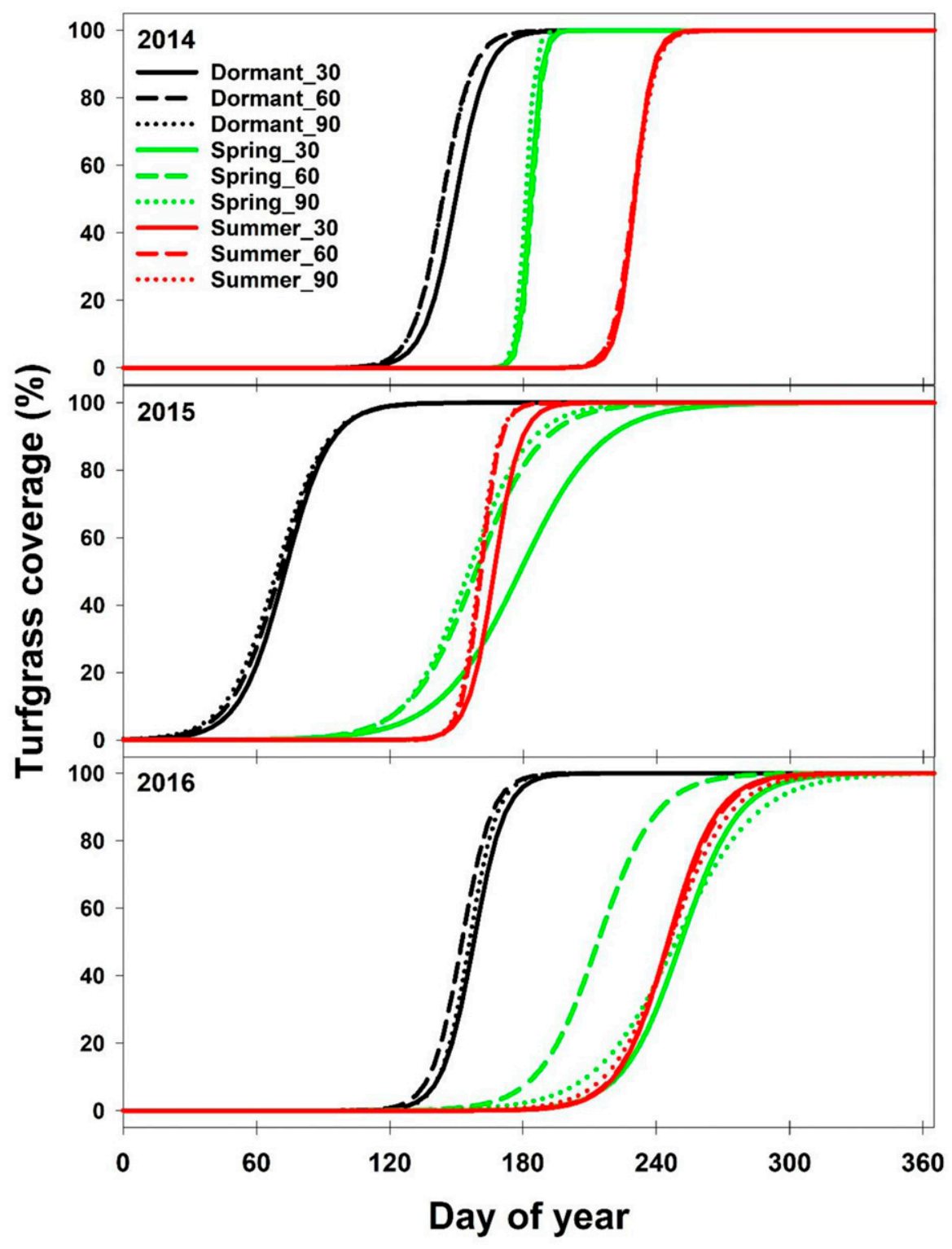

Fig. 3. Establishment of bermudagrass from sprigs planted during three seasons (dormant, spring, and summer) and with three planting rates $(30,60$, and $\left.90 \mathrm{~m}^{3} \cdot \mathrm{ha}^{-1}\right) ; 1 \mathrm{~m}^{3} \cdot \mathrm{ha}^{-1}=14.2913 \mathrm{ft}^{3} /$ acre.

4 to 12 weeks earlier in the growing season than either spring- or summerplanted bermudagrass. For many construction or renovation projects, this early establishment could significantly impact the overall economic success of a project. Recent work (Herrmann et al., 2020) also has demonstrated the effectiveness of dormant sprigging with bermudagrass. In that trial, 'Latitude 36' sprigs were planted in January, February, or March in Blacksburg, VA, and they reported full establishment by early July with all three dormant sprigging dates.

GDD REQUIREMENTS. As expected, GDD units initially accumulated more slowly with dormant plantings, but also resulted in the most available GDD units across the entirety of the growing season (Fig. 4). As noted in previous literature on dormant seeding (Pornaro et al., 2016; Shaver et al., 2006), dormant planting allows the seeds to initiate growth as early in the season as possible based on its biological requirements for temperature and moisture. Although no attempt was made in the present study to determine the soil or air temperature when growth was initiated, it is assumed that some biological activity was initiated when soil temperatures reached $5{ }^{\circ} \mathrm{C}$ (Unruh et al., 1996).

The GDD units required to establish zoysiagrass and bermudagrass from sprigs were variable from year to year and across planting seasons (Table 3). Interestingly, the dormant-sprigged treatments had more consistent GDD requirements across the 3 years of the trial compared with the spring and summer plantings (Table 3). For zoysiagrass, dormantsprigged treatments needed, on average, 1800 GDD units to reach $90 \%$ coverage, with required GDD units ranging from 1561 up to 2176 GDD units (Table 3). Dormant-sprigged bermudagrass treatments needed an average of 705 GDD units (base temperature of $5{ }^{\circ} \mathrm{C}$ ) to reach $90 \%$ coverage with a range from 536 up to 964 GDD units (Table 3 ). In comparison, spring-planted zoysiagrass required between 1773 and 2664 GDD units to reach $90 \%$ coverage, whereas bermudagrass required from 475 to 2412 GDD units. A broad range of GDD units was also observed with summerplanted sprigs (Table 3).

Although the authors are not aware of any research that has investigated the GDD units required to reach full coverage after sprigging a warmseason grass, Peterson et al. (2010) used accumulated GDD units to estimate the vitality of buffalograss (Buchloë dactyloides) sprigs for establishment. In that study, they demonstrated better establishment with early-harvested sprigs $(<120$ GDD units accumulated at harvest) compared with sprigs harvested later in the growing season. The earliest harvest date was described to be soon after the buffalograss broke dormancy, which would be more similar to the dormant-sprigged treatments in the present trial.

There is a limited body of re- search on GDD and sprig establishment of warm-season turfgrasses, so it is difficult to speculate why GDD units were a more consistent predictor of establishment in dormantsprigged treatments compared with spring or summer plantings. With later planting dates, the accumulation of GDD units starts immediately at planting, even though it may take sprigs as much as 2 to 3 weeks to root and initiate growth. With dormant sprigging, the initiation of growth and the accumulation of GDD units are likely to occur along a similar timeline 


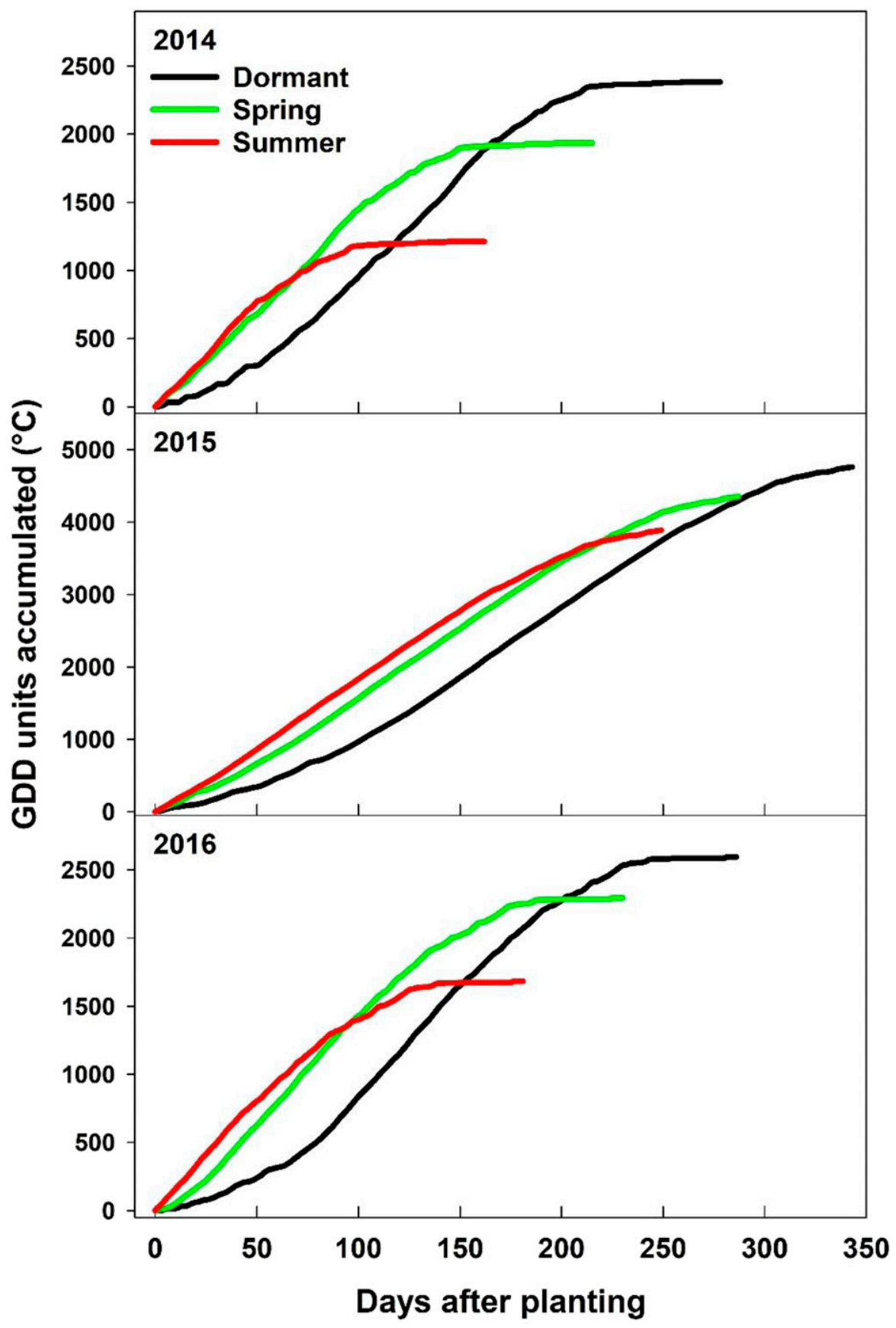

Fig. 4. Accumulation of growing degree day units [base temperature of $5^{\circ} \mathrm{C}(41.0$ $\left.{ }^{\circ} \mathrm{F}\right)$ ] after sprigging bermudagrass and zoysiagrass in three different seasons (dormant, spring, and summer).

and, therefore, be a more consistent predictor from year to year. Further work is certainly warranted to model growth from vegetative sprigs, especially to understand temperature and moisture effects on growth initiation.

\section{Conclusions}

This study clearly demonstrated that both zoysiagrass and bermudagrass can be sprig-planted during the late part of the dormant season in projects, as it is cost-prohibitive. Dormant sprigging may allow sod growers to produce a zoysiagrass crop within a 6- to 9-month window, which could allow the price to be more competitive with other turfgrass species in the marketplace. In addition, it might also allow lower-cost sprigging to be used in certain situations such as golf course or landscape development projects when a full growing season is available for turfgrass establishment. In bermudagrass, full establishment during the first season was attained with dormant, spring, or summer plantings, so success could be achieved with any planting dates. However, even with bermudagrass, there was a 2 - to 3 month advantage to reach full coverage by sprigging during the dormant season rather than waiting until a late spring or summer planting date.

As has been observed previously, higher sprigging rates are generally recommended for establishing zoysiagrass and we also observed a benefit of higher sprigging rates, especially when planting in spring or summer. However, higher sprigging rates did not provide a benefit when dormant planting was used. There were no consistent advantages to higher sprigging rates with bermudagrass.

It should be noted that cultivar will likely also have a major impact on the overall success of dormant sprigging. We have conducted dormant sprigging trials at the Arkansas site using the greens-type bermudagrass cultivar, Tifeagle, and have observed modest to poor results when dormant sprigging this cultivar (M.D. Richardson, unpublished data). Because 'Tifeagle' is a diminutive, dwarf cultivar, it may lack the energy reserves in stolons or rhizomes to be successfully established in the dormant season. Although several papers have demonstrated variability in stolon size characteristics (Magni et al., 2014; Reasor et al., 2016; Roche and Loch, 2005), there are minimal data on the variability in rhizome traits of bermudagrass cultivars, even though recent evidence demonstrates that variability indeed exists (Pornaro et al., 2019). Future research should also focus on investigations of other warm-season grasses that are commonly sprigged, such as st. augustinegrass (Stenotaphrum secundatum), centipedegrass (Eremochloa 
Table 3. Growing degree day (GDD) units required to reach $90 \%$ coverage when sprigging zoysiagrass or bermudagrass in various seasons (dormant, spring, or summer) and at various planting rates. Trials were repeated over 3 years (2014, 2015, and 2016).

\begin{tabular}{|c|c|c|c|c|c|c|c|c|}
\hline \multirow{2}{*}{$\begin{array}{l}\text { Planting } \\
\text { season }\end{array}$} & \multirow[b]{2}{*}{ Yr } & \multirow{2}{*}{$\begin{array}{c}\text { Planting rate } \\
\left(\mathrm{m}^{3} \cdot \mathrm{ha}^{-1}\right)^{\mathrm{z}}\end{array}$} & \multicolumn{3}{|c|}{ Zoysiagrass } & \multicolumn{3}{|c|}{ Bermudagrass } \\
\hline & & & Lower 95\% CI ${ }^{\mathrm{y}}$ & Mean & Upper 95\% CI & Lower 95\% CI & Mean & Upper $95 \% \mathrm{CI}$ \\
\hline & & & \multicolumn{6}{|c|}{ GDD units to reach $90 \%$ coverage $^{y}$} \\
\hline \multirow[t]{9}{*}{ Dormant } & 2014 & 30 & 1,561 & 1,693 & 1,861 & 716 & 748 & 765 \\
\hline & & 60 & 1,561 & 1,713 & 1,894 & 598 & 634 & 686 \\
\hline & & 90 & 1,712 & 1,819 & 1,986 & 598 & 652 & 689 \\
\hline & 2015 & 30 & 1,682 & 1,766 & 1,849 & 575 & 618 & 670 \\
\hline & & 60 & 1,642 & 1,721 & 1,808 & 575 & 593 & 605 \\
\hline & & 90 & 1,682 & 1,766 & 1,788 & 536 & 575 & 605 \\
\hline & 2016 & 30 & 1,725 & 1,890 & 2,036 & 805 & 887 & 964 \\
\hline & & 60 & 1,686 & 1,841 & 1,996 & 773 & 789 & 821 \\
\hline & & 90 & 1,770 & 1,975 & 2,176 & 805 & 854 & 904 \\
\hline \multirow[t]{9}{*}{ Spring } & 2014 & 30 & 2,196 & 2,322 & 2,436 & 598 & 616 & 649 \\
\hline & & 60 & 1,773 & 1,852 & 1,947 & 598 & 631 & 649 \\
\hline & & 90 & 1,917 & 2,009 & 2,069 & 475 & 576 & 668 \\
\hline & 2015 & 30 & 2,195 & 2,342 & 2,492 & 2,014 & 2,115 & 2,221 \\
\hline & & 60 & 2,195 & 2,342 & 2,517 & 1,526 & 1,622 & 1,695 \\
\hline & & 90 & 2,168 & 2,342 & 2,542 & 1,477 & 1,526 & 1,597 \\
\hline & 2016 & 30 & 2,251 & 2,487 & 2,664 & 2,187 & 2,251 & 2,309 \\
\hline & & 60 & 2,340 & 2,505 & 2,651 & 1,416 & 1,523 & 1,639 \\
\hline & & 90 & 2,295 & 2,466 & 2,619 & 2,005 & 2,208 & 2,412 \\
\hline \multirow[t]{9}{*}{ Summer } & 2014 & 30 & $n a^{x}$ & na & na & 511 & 531 & 578 \\
\hline & & 60 & na & na & na & 511 & 531 & 578 \\
\hline & & 90 & na & na & na & 511 & 531 & 578 \\
\hline & 2015 & 30 & 1,958 & 1,982 & 2,028 & 1,136 & 1,161 & 1,187 \\
\hline & & 60 & 1,982 & 2,028 & 2,051 & 966 & 989 & 1,014 \\
\hline & & 90 & 1,910 & 1,982 & 2,005 & 966 & 989 & 1,014 \\
\hline & 2016 & 30 & na & na & na & 1,207 & 1,284 & 1,351 \\
\hline & & 60 & na & na & na & 1,227 & 1,299 & 1,373 \\
\hline & & 90 & na & na & na & 1,299 & 1,299 & 1,375 \\
\hline
\end{tabular}

${ }^{\mathrm{z}} 1 \mathrm{~m}^{3} \cdot \mathrm{ha}^{-1}=14.2913 \mathrm{ft}^{3} /$ acre.

${ }^{y}$ GDD units [base temperature of $5^{\circ} \mathrm{C}\left(41.0^{\circ} \mathrm{F}\right)$ ] needed to reach $90 \%$ turfgrass coverage. Means for each treatment combination were considered statistically different if their $95 \%$ confidence intervals $(\mathrm{CI})$ did not overlap.

${ }^{\mathrm{x}} \mathrm{na}=$ not applicable

ophiuroides), and seashore paspalum (Paspalum vaginatum).

A potential challenge with dormant sprigging will be the ability to prepare fields for planting during mid or late winter, as weather conditions during that period may make it difficult to adequately address soil preparation. This could be an issue for golf courses and athletic fields and may be a bigger challenge in sod production. It would be worthwhile to determine if dormant sprigging could be effectively accomplished with no-till sprigging equipment to avoid the use of more aggressive tillage equipment during the late winter.

\section{Literature cited}

Baseggio, M., Y.C. Newman, L.E. Sollenberger, C. Fraisse, and T. Obreza. 2015. Stolon planting rate effects on Tif- ton 85 bermudagrass establishment. Agron. J. 107:1287-1294, doi: 10.2134/ agronj14.0188.

Bingham, S.W. and J.R. Hall, III. 1985. Effects of herbicides on bermudagrass (Cynodon spp.) sprig establishment. Weed Sci. 33:253-257, doi: 10.1017/ S0043174500082205.

Brosnan, J.T., G.K. Breeden, A.W. Thoms, and J.C. Sorochan. 2014. Effects of preemergence herbicides on the establishment rate and tensile strength of hybrid bermudagrass sod. Weed Technol. 28:206-212, doi: 10.1614/WT-D-1300102.1 .

Chamblee, D.S., J.P. Mueller, and D.H. Timothy. 1989. Vegetative establishment of three warm-season perennial grasses in late fall and late winter. Agron. J. 81: 687-691, doi: 10.2134/agronj1989. $00021962008100040025 x$.
Christians, N.E., A.J. Patton, and Q.D. Law. 2017. Fundamentals of turfgrass management. 5th ed. Wiley, Hoboken, NJ, doi: 10.1002/9781119308867.

Engelke, M. 1988. Zoysiagrass turf: Its strength and weaknesses. Golf Course Manage. 1988(Mar):50-66.

Giolo, M., C. Pornaro, A. Onofri, and S. Macolino. 2020. Seeding time affects bermudagrass establishment in the transition zone environment. Agronomy 10: 1151, doi: 10.3390/agronomyl0081151.

Guertal, E.A. and D.L. Evans. 2006. Nitrogen rate and mowing height effects on TifEagle bermudagrass establishment. Crop Sci. 46:1772-1778, doi: 10.2135/ cropsci2006.01-0006.

Guertal, E.A. and C.A. Hicks. 2009. Nitrogen source and rate effects on the establishment of 'TifSport' and 'Tifway' hybrid bermudagrass. Crop Sci. 49:690695, doi: 10.2135/cropsci2008.07.0436. 
Hanna, W., P. Raymer, and B. Schwartz. 2013. Warm-season grasses: Biology and breeding, p. 543-590. In: J.C. Stier, B.P. Horgan, and S.A. Bonos (eds.). Turfgrass: Biology, use, and management. Amer. Soc. Agron. Madison, WI, doi: 10.2134/ agronmonogr56.cl6.

Herrmann, M., J.M. Goatley, Jr., D.S McCall, and S.D. Askew. 2020. Establishment of dormant 'Latitude 36' bermudagrass sprigs in the transition zone. Crop. Forage Turfgrass Manag., doi: $10.1002 / \mathrm{cft} 2.20087$.

Johnson, B.J. 1980. Differences in tolerance of bermudagrass and zoysiagrass cultivars to herbicides. Intl. Turfgrass Soc. Res. J. 3:217-225, doi: 10.2135/1974. proc3rdintlturfgrass.c25.

Keeley, P.E. and R.J. Thullen. 1989. Infuence of planting date on growth of bermudagrass (Cynodon dactylon). Weed Sci. 37:531-537, doi: 10.1017/ S0043174500072362.

Magni, S., M. Gaetani, L. Caturegli, C. Leto, T. Tuttolomondo, S. La Bella, V. Salvatore, N. Giuseppe, N. Ntoulas, and M. Volterrani. 2014. Phenotypic traits and establishment speed of 44 turf bermudagrass accessions. Acta Agr. Scand. Sect. B Soil Plant Sci. 64:722-733, doi: $10.1080 / 09064710.2014 .955524$.

McCarty, L.B. and G. Miller. 2002. Managing bermudagrass turf. Selection, construction, cultural practices, and pest management. Ann Arbor Press, Chelsea, MI.

Miller, G.L. and R. Dickens. 1996. Bermudagrass carbohydrate levels as influenced by potassium fertilization and cultivar. Crop Sci. 36:1283-1289, doi: 10.2135/cropscil996. 0011183X003600050035x.

Mueller, J.P., J.T. Green, D.S. Chamblee, J.C. Burns, L. Goode, J.V. Baird, J.E. Bailey, and J. Failter. 1981. Hybrid bermudagrass. North Carolina Agr. Ext. Serv. AG-265.

Musser, H.B. and A.T. Perkins. 1969. Guide to planting, p. 447-490. In: A.A. Hanson and F.V. Juska (eds.). Turfgrass science. Agron. Monogr. 14, Amer. Soc. Agron., Madison, WI, doi: 10.2134/ agronmonogr14.cl8.

Patton, A.J. 2009. Selecting zoysiagrass cultivars: Turfgrass quality, growth, pest and environmental stress tolerance. Appl. Turfgrass Sci. 6(1):1-18, doi: 10.1094/ ATS-2009-1019-01-MG.

Patton, A.J., G.A. Hardebeck, D.W. Williams, and Z.J. Reicher. 2004. Establishment of bermudagrass and zoysiagrass by seed. Crop Sci. 44:2160-2167, doi: 10.2135/cropsci2004.2160.
Patton, A.J., B.M. Schwartz, and K.E. Kenworthy. 2017. Zoysiagrass (Zoysia spp.) history, utilization, and improvement in the United States: A review. Crop Sci. 57:37-72, doi: 10.2135/cropsci2017. 02.0074

Patton, A.J., J.J. Volenec, and Z.J. Reicher. 2007. Stolon growth and dry matter partitioning explain differences in zoysiagrass establishment rates. Crop Sci. 47:12371245. doi: 10.2135/cropsci2006.10.0633.

Peterson, K.W., R.C. Shearman, R.E. Gaussoin, G.L. Horst, and W.H. Schacht. 2010. Growing degree-day influence on sprigged establishment of two buffalograss cultivars. HortScience 45:293-298, doi: 10.21273/HORTSCI.45.2.293.

Pornaro, C., S. Macolino, and B. Leinauer. 2016. Seeding time affects establishment of warm-season turfgrasses. Acta Hort. 1122:27-34, doi: 10.17660/ ActaHortic.2016.1122.4.

Pornaro, C., S. Macolino, and M.D. Richardson. 2019. Rhizome and stolon development of bermudagrass cultivars in a transition-zone environment. Acta Agr. Scand. Sect. B Soil Plant Sci., doi: 10.1080/09064710.2019.1639805.

Reasor, E.H., J.T. Brosnan, R.N. Trigiano, J.E. Elsner, G.M. Henry, and B.M. Schwartz. 2016. The genetic and phenotypic variability of interspecific hybrid bermudagrasses (Cynodon dactylon (L.) Pers $\times$ C. transvaalensis Burtt-Davy) used on golf course putting greens. Planta 244:761-773, doi: $10.1007 / \mathrm{s} 00425$ 016-2573-8.

Reicher, Z.J., C.S. Throssell, and D.V. Weisenberger. 2000. Date of seeding affects establishment of cool-season turfgrasses. HortScience 35:1166-1169, doi: 10.21273/HORTSCI.35.6.1166.

Richardson, M.D. and J.W. Boyd. 2001. Establishing Zoysia japonica from sprigs: Effects of topdressing and nitrogen fertility. HortScience 36:377-379, doi: 10.21273/HORTSCI.36.2.377.

Richardson, M.D., J.W. Boyd, and J.H. McCalla. 2003. A net-planting technique for establishing zoysiagrass from sprigs. HortTechnology 13:74-76, doi: 10.21273/ HORTTECH.13.1.0074.

Richardson, M.D., D.E. Karcher, and L.C. Purcell. 2001. Quantifying turfgrass cover using digital image analysis. Crop Sci. 41:1884-1888, doi: 10.2135/ cropsci2001.1884.
Roche, M.B. and D.S. Loch. 2005. Morphological and developmental comparisons of seven greens quality hybrid bermudagrass [Cynodon dactylon (L.) Pers. $\mathrm{x}$ C. transvaalensis Burtt-Davy]. Intl. Turfgrass Soc. Res. J. 10:627-634.

Ross, K.J. 2003. Dormant seeding: A different approach. Golf Course Manage. 71(9):70-73.

Ruemmele, B.A., M.C. Engelke, S.J. Morton, and R.H. White. 1993. Evaluating methods of establishment for warmseason turfgrasses. Intl. Turfgrass Soc. Res. J. 7:910:916.

Rusland, G.A., L.E. Sollenberger, and C.S. Jones. Jr. 1993. Nitrogen fertilization effects on planting stock characteristics and establishment performance of dwarf elephantgrass. Agron. J. 85: 857-861, doi: 10.2134/agronj1993. $00021962008500040015 x$.

Schiavon, M., S. Macolino, B. Leinauer, and U. Ziliotto. 2016. Seasonal changes in carbohydrate and protein content of seeded bermudagrasses and their effect on spring green-up. J. Agron. Crop Sci. 202:151-160, doi: 10.1111/jac.12135.

Shaver, B.R., M.D. Richardson, J.H. McCalla, D.E. Karcher, and P.J. Berger. 2006. Dormant seeding bermudagrass cultivars in a transition-zone environment. Crop Sci. 46:1787-1792, doi: 10.2135/cropsci2006.02-0078.

Shoulders, J.F. and R.E. Schmidt. 1985. Establishing Cynodon spp. from dormant vegetative propagules. Proc. Intl. Turfgrass Soc. p. 307-310.

Stiglbauer, J.B., H.B. Liu, L.B. McCarty, D.M. Park, J.E. Toler, and K. Kirk. 2009. 'Diamond' zoysiagrass putting green establishment affected by sprigging rates, nitrogen sources, and rates in the southern transition zone. HortScience 44:1757-1761. doi: 10.21273/HORTSCI.44.6.1757.

Unruh, J.B., R.E. Gaussoin, and S.C. Weist. 1996. Basal growth temperatures and growth rate constants of warmseason turfgrass species. Crop Sci. 36: 997-999, doi: $10.2135 /$ cropscil 996 . 0011183 X0036000400030x.

Webb, B.C. 1959. Comparison of water loss and survival of Coastal bermudagrass stolons harvested at two stages of growth. Agron. J. 51:367-368, doi: 10.2134/ AGRONJ1959.00021962005100060020X. 